\title{
An Event Study Approach to Analyse the Impact of Novel Coronavirus Disease (Covid-19) on Indian Hotel \& Tourism Stocks Performance
}

\author{
Saurabh Agarwal ${ }^{1}$, Megha Agarwal $^{2}$ and Renu Ghosh3, *, $\dagger$ \\ ${ }^{1}$ IIF College of Commerce and Management Studies, CCS University, India and ${ }^{2}$ Department of Commerce, \\ Rajdhani College, University of Delhi, India and ${ }^{3}$ Dyal Singh College, Kurukshetra University, India. \\ *renu20102010@gmail.com \\ ${ }^{\dagger}$ Corresponding author.
}

\begin{abstract}
Covid 19 or the Novel Corona Virus outbreak in 2020 has disrupted the world and Indian economy. Tourism industry has suffered the most due to this outbreak. The hotel industry stocks have experience an average fall of twenty three percent within a month of the Covid 19 outbreak. With the help of event-study approach, an attempt has been made to analyse the effect of Covid 19 on Indian hotel stock price movements. Six publicly traded hotel and tourism companies experience a steep fall in their stock prices during the Covid 19 outbreak period. On and after the day the World Health Organisation declared Covid 19 a pandemic, Indian hotel stocks exhibited significant negative cumulative mean abnormal returns, indicating a significant impact of the Covid 19 outbreak on hotel stock performance. Empirical finding can enable Businesses to prepare themselves for alternate uses like isolation wards and save themselves from economic plight.
\end{abstract}

JEL Classification: G10; G14; C22; C25. Keywords: Covid 19; Stock returns; Event study; Negative Returns.

\section{Introduction}

Coronavirus disease (Covid-19) is a highly transmittable and viral infection. The virus emerged in Wuhan, China and then spread to the world. It has affected 188 countries affecting 138,302,131 people and resulting in the death of more than 2,973,874 people across the world (John Hopkins University Covid-19 dashboard (Johns Hopkins University, 2020)). In humans, the virus spread by exposure to droplets of infected person by coughing, sneezing, respiratory droplets or aerosols. An infected person may show sign of cough, fever and shortness of breath. Many infected person continue to carry the infection asymptotically while affecting others. Unfortunately, there is no approved antiviral drug or vaccine available to counter COVID-19. Corona virus is represented by crown-like spikes on a ball. Corona Virus causes acute lung injury and acute respiratory distress syndrome resulting in pulmonary failure and death in some cases. Those having strong immunity recover from this infection. Mortality rate is low i.e. $3.61 \%$ (Shereen et al., 2020).

On 11 March 2020, World Health Organisation (WHO) declared Novel Coronavirus Disease (COVID-19) outbreak as a pandemic. World Health Organisation has asked all the countries to save lives by developing suitable strategy to deal with the situation. A number of countries have resorted to lockdown thereby limiting all economic activities except those which are essential for survival. Government of India issued its first travel advisory in January 
2020 and finally on 19th March thereby stopping all international commercial passenger aircraft from March 22nd to May 3rd, 2020 (Ministry of Health \& FW, Government of India, 2020). Aeroplanes carrying freight were still allowed. Domestic flights were suspended from March 24 to May 3rd 2020 (The Economic Times, 2020). With such restrictions on international and domestic travel, the hotel industry is expected to face a lot of financial distress. It is expected that the revenue of hotel and hospitality industry to dip by 30 per cent. The net impact is expected to $\$ 1.5$ billion dollars (The Hindu BusinessLine, 2020). This will adversely affect the employment in this sector and loss of foreign exchange reserves earned by this sector.

The global economy is expected to shrink by 1 per cent due to coronavirus pandemic (United Nations). The pandemic has disrupted global supply chains and international trade with more than 100 countries imposing travel related restrictions. This financial loss can be offset by an increase in the government spending. The fiscal spending will only make an impact if the duration of this pandemic is not extended beyond a few months. Many governments have announced financial bailout packages to nullify the negative impact of Covid 19. India itself has announced a bailout package of US $\$ 22$ bn to help the poor from the negative effects of Corona virus (BBC News, 2020). Coronavirus had a negative impact on Indian Stock markets. Both Sensex and Nifty have fallen by 33 percent (Business Today). This sort of decline was last observed during the financial crises of 2008.

"Investing in speculative assets is a social activity. Investors spend a substantial part of their leisure time discussing investments, reading about investments, or gossiping about others' successes or failures in investing. It is plausible that investors' behaviour (and hence prices of speculative assets) would be influenced by social movements". Epidemic model of investor behaviour modelling the infection rate of diseases and stock prices has also been created (Shive, 2010). A socially influenced motivated trading can predict future stock returns.

Previously, pandemics occurred: (a) in 1918 the "Spanish influenza (H1N1 Virus)", (b) in 1957 the "Asian influenza (H2N2 Virus)", (c) in 1968 the "Hong Kong influenza (H3N2 Virus)", (d) in 2005 the "H5N1 avian influenza", (e) in 2009 "H1N1 pdm09 virus" and (f) in 2020 the "Coronavirus (Covid 19)". Most of the studies on the impact of pandemics analyse the effect on the fall in demand of various discretionary spending sectors like Hotels, Airlines and retail. There exists limited literature undertaking event study to analyse the impact of such pandemics on stock market returns. The impact of SARS outbreak on Taiwanese hotel stock performance (Chen et al., 2007) and SARS impact on Airline stocks (Loh, 2006) have been investigated in the past using event study methodology.

This paper has been divided into six sections. First section introduces the concept and research objectives. Section two focuses on review of literature, Section three discusses the Data and methodology, Section four discusses the results and analysis, section five concludes the paper with possible managerial implications and section six points out the limitations and scope for future research.

\section{Research Objectives}

i. To study the impact of Covid-19 on stock return of hotel and tourism companies in India using Event-Study Methodology (EVM).

ii. To compare the mean returns of pre and post Covid 19 announcement by World Health Organisation (WHO).

\section{Literature Review}

The impact of SARS was found to be transitional and not a long run phenomenon (Loh, 2006). The research work could not find any evidence to show negative impact of SARS on mean market returns of airline stocks and market indexes. SARS also had a minuscule effect on volatility of market returns except for Singapore. However, volatility of airline stocks increased thereby increasing the financial risk. Hence, volatility tests were recommended. The effect of SARS was found to be negligible for financial assets. The results are based on twelve airline companies listed on exchanges of Canada, China, Hong Kong, Singapore, Taiwan and Thailand.

Hotel stock faced higher risk during the SARS outbreak. Negative Cumulative mean abnormal returns (CARs) were observed for the hotel and foods industries (Chen et al., 2007). They found that seven publicly traded hotel companies had a significant decline in earnings and stock prices during the SARS period. Irrational market response led to severe sell-offs negatively affecting market valuations. The results are based on seven hotels listed on the Taiwan Stock Exchange.

The expectation about the performance of the economy also reduces with increase in flu incidences (McTier et al., 2013). They found that flu results in decrease in trading activity and stock returns. Volatility also reduces. Bid-ask spread widens with increase in the incidence of flu. Flu results in limited activity by traders and market makers. The results were based on international stock market data from twenty-five country market indices. Regression models have been used to study the impact of pandemic on market capitalisation (Alfaro et al., 2020). It was found that doubling of infections by SARS and Covid-19 is associated with a 4 to 11 percent decline in market capitalization for the entire index. The return volatility will reduce once the infection rate becomes more certain. Their prediction model was applied to SARS outbreak in Hong Kong and Covid-19 pandemic in United States.

Panel data regression analysis identified the impact of Covid 19 on Chinese Stock Market (Al-Awadhi et al., 2020). An inverse relationship was found between growth in total confirmed cases and deaths on one hand and fall in stock returns on the other hand. The analysis is based on all companies included in the Hang Seng Index and 
Shanghai Stock Exchange Composite Index over the period of 10 January to 16 March 2020. Information Technology and Medicine Manufacturing sectors performed better than other sectors. Shares having higher foreign investment exhibited higher negative returns than those stocks which are traded by Chinese citizens only. Companies with higher market capitalization faced a greater decline in returns. Risk and uncertainty of financial markets globally has increased due to Covid-19 (Zhang et al., 2020). Various monetary and fiscal policy initiatives have further added to uncertainties surrounding financial markets. From Volatility analysis, it was observed that China has the highest level of standard deviation in February. The correlations across twelve countries increase in the week ending on 6th March, 2020. The correlations reduced by week ending 20th March, 2020.

Comparison of the impact of Covid 19 pandemic on stock market with reference to the Spanish Flu of 1918-20 has been conducted (Baker et al., 2020). Using text-based methods, they found that not even a single event since 1900 has led to such a large daily market movements. Covid 19 has led to large daily U.S. stock market moves since 24th February 2020. Policy prescriptions like travel restrictions, social distancing mandates, Lockdown etc. is resulting in great economic damage finally impact the stock markets.

Using GARCHX model (Apergis and Apergis, 2020) proved that Covid-19 has a significant negative impact on stock returns and a statistically significant positive impact on the volatility of these market returns . The analysis has used two alternative proxies' namely (i) total confirmed cases and (ii) total daily deaths for Covid-19. The results were based on Chinese stock market returns and their volatility over the period 22 January 2020 through 30 April 2020 i.e. daily data. A type of shares i.e. share restricted to Chinese citizens has been investigated as a part of this study.

Event study analysis of Covid-19 and Index returns based on return for 30 countries has also been attempted (Bash, 2020). Significant Negative returns were observed due to Covid-19 outbreak. The event windows used were $[-1,1],[-3,3],[-5,5],[-10,10],[-10,15]$ and $[-10,20]$ from the first registered case in the respective country.

Recently, a study on the impact of policy initiatives on stock market returns of G7 countries has been undertaken (Narayan et al., 2021). They have used time series data from 1 July 2019 to 16 April 2020. They ran multiple regressions with country stock index return as the dependent variable and lockdown, package, travel ban, crude oil return and stock return volatility as independent variables. It was found that all policies had a positive effect on G7 Country stock market excess returns. Hence, positive government responses can help in reducing the negative effect of Covid-19.

The impact of Covid-19 on healthcare and pharmaceutical sector stocks has been studied (Mittal and Sharma, 2021). Analysis is based on sector specific indices for 233 days ranging from 15 May 2019 to 24 April 2020. Event study methodology has been used to calculate abnormal returns and cumulative abnormal return. BSE Health care index gave positive returns unlike many other sector indices which gave negative returns during post-event period.

Research has also been undertaken to focus on uncovering the relationship of Covid-19 outbreak, macroeconomic fluctuations and hospitality stock returns using structural VAR framework from 13 January to 11 May 2020 in China (Lee et al., 2021). Covid-19 outbreak significantly affected hospitality stock returns. An increase in exchange rate (currency depreciation) led to negative stock market returns for hospitality stocks and vice versa. A dynamic relationship was observed between macroeconomic fluctuations and hospitality stock returns.

\section{Data and methodology}

\subsection{Background}

Event-Study Methodology (EVM) is popularly and widely used in the literature to assess the impact of an economic event (announcement of news whether positive or negative) on the economic value (stock prices/returns) of a firm. Therefore, present study uses Event-study methodology to investigate the impact of announcement of Covid-19 as pandemic by WHO on the stock returns of hotel and tourism companies listed in S\&P CNX Nifty-500 equity index, the widest equity market index in India. Covid-19 was declared as pandemic by WHO on $11^{\text {th }}$ March, 2020.

The movements in the stock returns of any company may be caused either by market specific events or firm specific events. The movements that arise in the economic value of any firm due to firm specific events are called 'Abnormal Returns (ARs)'. If the economic event announced is good for the firm, then Abnormal returns are expected to be positive, reflecting the market behaviour believing that the event announced will increase the value of the firm. On the other hand, if the announcement is the bad news, then abnormal returns are expected to be negative.

\subsection{Methodology}

\subsubsection{Sample}

The sample for the purpose of study consists of six Hotel and Tourism Industry companies listed in S\&P CNX Nifty500 index that has continuous available prices for the period under consideration. The list of sample companies along with average market capitalization and date of listing in Nifty-500 is provided in Table 1.

These companies represent a broad spectrum as they belong to one of the eighteen major sectors of the economy. The adjusted closing stock prices are collected on daily basis. Daily Standardized Abnormal Returns for individual 
Table 1. Hotel and Tourism Companies Listed in National Stock Exchange (NSE-500)

\begin{tabular}{lcc}
\hline Company Name & Date of listing & $\begin{array}{c}\text { Average Market } \\
\text { Capitalization } \\
\text { (Rs. Crore) }\end{array}$ \\
\hline Chalet Hotels Ltd. & $07-02-2019$ & 6734.40 \\
E I H Ltd. & $25-11-1994$ & 9287.34 \\
India Tourism Development Corporation Ltd. & $30-12-2016$ & 2333.25 \\
Indian Hotels Co. Ltd. & $03-11-1994$ & 17319.09 \\
Lemon Tree Hotels Ltd. & $09-04-2018$ & 4893.66 \\
Mahindra Holidays \& Resorts India Ltd. & $16-07-2009$ & 2994.86 \\
\hline
\end{tabular}

Note: The average market capitalization is for the window estimation period covering 201 trading days starting from 2nd April, 2019 - 27th January, 2020.

Source: CMIE Prowess

company are then used to create equally weighted portfolio abnormal returns as there is a trade-off between using portfolio data and individual firm data. When the individual firm data is used, the noise is high in the data and results may be unduly influenced by the individual company multinational characteristics. On the other hand, formation of portfolio returns has the advantage of smoothing out the noise in the individual data due to transitory shocks but it has the disadvantage of ignoring the dissimilarities in the individual firm characteristics. Therefore, the present study analysed both hotel and tourism industry cumulative abnormal returns as well as individual company's cumulative abnormal returns to accommodate these arguments.

The stock prices and market capitalization data have been taken from PROWESS- the online database maintained by the Centre for Monitoring of Indian Economy (CMIE). This database contains all the actively traded stocks listed in Bombay Stock Exchange and National Stock Exchange.

The return on the S\&P CNX Nifty-500 equity index, the widest equity market index in India is used as a proxy for market portfolio. It is a broad-based value weighted market index generally used in research studies. The data regarding index values have also been collected from NSE website and Prowess database.

\subsubsection{Research Design}

The date when any economic event is announced is called 'event date'. In the present study, event date is 11th March 2020, when the outbreak of Covid-19 is declared as pandemic by WHO (World Health Organization). The period for which we wish to assess the effect of announced news on stock prices is called 'Event Window' $t=[-t 1$, t2]. For example, event window $[-10,10]=21$ days indicates 10 days prior and 10 days after the event. Similarly, event window $[-10,0]$ indicates the period starting from 10 days prior to the date of announcement of economic event. The day ' 0 ' indicates date of announcement of economic event.

The impact of announcement of Covid-19 pandemic is analysed by testing the statistical significance of cumulative mean abnormal returns over the different event windows. The statistical significance of CARs indicates that the covid-10 pandemic has significant effect on stock returns of hotel and tourism companies listed in Nifty-500.

\subsubsection{Estimation of Abnormal Returns}

3.2.2.1.1 Calculation of Stock Returns First, we calculate the logarithmic returns for each hotel and tourism company listed in Nifty-500. For the analysis, we used 201 trading days for the window estimation period starting from 2 nd April, 2019 to 27 Jan, 2020.

$$
R_{(i, t)}=\ln \left(\frac{P_{(i, t)}}{P_{(i, t-1)}}\right) * 100
$$

Where, $R_{(i, t)}$ is the return of stock $i$ on day $t ; P_{(i, t)} \& P_{(i, t-1)}$ is the price of stock $i$ on day $t$ and $t-1$, respectively. On the similar lines, the returns on market index, S\&P CNX Nifty-500 equity index, the widest equity market index in India is calculated:

$$
R_{(m, t)}=\ln \left(\frac{V_{(m, t)}}{V_{(m, t-1)}}\right) * 100
$$

Where, $R_{(m, t)}$ is the return on market index at day $t ; V_{(m, t)} \& V_{(m, t-1)}$ are the values of index at day $t$ and $t-1$, respectively.

\subsection{Estimation of Stock Returns}

Estimation of Stock Returns via OLS-MM model : To measure the Abnormal Returns (ARs) of stock i at day t, we need to calculate the estimated returns of stock i at day t. All hotel and tourism industry company's stock 
returns are estimated by running following regression of Market Model (MM model). We regressed the stock returns of each hotel and tourism company against market returns to control the effect of market specific events. The difference between the actual returns and estimated returns are the abnormal returns attributed as returns caused by firm-specific events. The regression model used is given as:

$$
\begin{gathered}
R_{(i, t)}=\alpha_{i}+\beta_{i} \cdot R_{(m, t)}+\epsilon_{(i, t)} \\
\epsilon_{(i, t)} \sim N\left(0, \sigma^{2}\right)
\end{gathered}
$$

Where $R_{(i, t)}$ is the return of stock $i$ on day $t ; R_{(m, t)}$ represents returns on market index at day $t ; \alpha_{i} \& \beta_{i}$ are the intercept and sensitivity coefficients to be estimated; $\epsilon_{(i, t)}$ denotes the residual of the regression and represent that part of the returns that cannot be explained by market returns. Then, the estimated return (ERs) given as equation 5 is calculated by employing the regression coefficients $\hat{\alpha}$ and $\hat{\beta}$ obtained by usingequation 3 via an Ordinary Least Square (OLS) model. The estimated returns of each hotel and tourism industry company is calculated for different event windows $t=\left[-t_{1}, t_{2}\right]$.

$$
E R_{(i, t)}=\hat{\alpha}_{i}+\hat{\beta}_{i} \cdot R_{(m, t)}
$$

where $E R_{(i, t)}$ is the estimated return of company $i$ at day $t$.

Estimation of Stock Returns via GARCH (1,1) model : Financial time series data are often characterized by Volatility Clustering and Leverage Effects (Brooks, 2019). Therefore, to obtain the good fit requires adopting a conditional distribution with fatter tails (ARCH-GARCH type models) rather than normal distributions (Bollerslev et al., 1992). Hence, we tested our data for the problem of Heteroscedasticity (time-varying variance that depends on lagged effects). If the ARCH effect is found to be significant then, it was decided to employ GARCH $(1,1)$ model, which takes care of these features of financial time series. GARCH $(1,1)$ model is sufficient to obtain a model fit for our data as GARCH $(1,1)$ model is more parsimonious and avoids overfitting. The GARCH $(1,1)$ process specified below is used to calculate estimated returns in case of those firms, where the problem of heteroscedasticity is found significant. The equations of GARCH $(1,1)$ Model is given as:

$$
\begin{gathered}
R_{(i, t)}=\alpha_{i}+\beta_{i} \cdot R_{(m, t)}+\epsilon_{(i, t)} \\
\epsilon_{(i, t)} / \varphi_{(t-1)} \sim N\left(0, h_{(i, t)}\right) \\
h_{(i, t)}=\alpha_{0}+\alpha_{1} \epsilon_{(i, t-1)}^{2}+\alpha_{2} h_{(i, t-1)}
\end{gathered}
$$

Where $R_{(i, t)}$ is the return of stock $i$ on day $t ; R_{(m, t)}$ represents returns on market index at day $t ; \alpha_{i} \& \beta_{i}$ are the intercept and sensitivity coefficients to be estimated; $\epsilon(i, t)$ denotes the residual of the regression and represent that part of the returns that cannot be explained by market returns; $h_{(i, t)}$ is the conditional variance since it is one-period ahead estimate for the variance calculated based on any past information $\left(\varphi_{(t-1)}\right)$ about volatility; $\alpha_{0}$ is the average volatility; $\alpha_{1}$ is the previous period's residual variance the ARCH term and $\alpha_{2}$ is the previous period's forecast variance the GARCH term.

Then, the estimated returns (ERs) given as equation 9 are calculated by employing the regression coefficients $\hat{\alpha}$ and $\hat{\beta}$ obtained by using equation 6 via GARCH $(1,1)$ model. The estimated returns for hotel and tourism industry company where ARCH effect is significant is calculated for different event windows $t=\left[-t_{1}, t_{2}\right]$.

$$
E R_{(i, t)}=\hat{\alpha}_{i}+\hat{\beta}_{i} \cdot R_{(m, t)}
$$

Where $E R_{(i, t)}$ is the estimated returns of company $i$ at day $t$.

3.2.2.1.3 Estimation of Abnormal Returns The Abnormal Returns (ARs) during the event window is computed given as follows:

$$
A R_{(i, t)}=R_{(i, t)}-E R_{(i, t)}
$$

Where $A R_{(i, t)}$ are the abnormal returns of company $i$ at day $t$; The abnormal returns obtained by using equation 10 represent movements in share prices caused by firm-specific event. 
3.2.2.1.4 Estimation of Standardized Abnormal Returns The estimation of Standardized abnormal returns can be done by using following statistics:

$$
S A R_{i, t}=\frac{A R_{(i, t)}}{S_{A R_{i}}}
$$

Where $S A R_{i, t}$ is the standardized abnormal returns of company $i$ at day $t$ and $S_{A R_{i}}$ is the standard deviation of abnormal returns in the estimation window with a length of $\mathrm{n}$ (201 days). We then calculate the standardized abnormal returns for the hotel and tourism industry (SARh) by aggregating the SARs of individual hotel and Tourism Company adjusted for the number of companies in the industry as is given in equation 12

$$
S A R_{h}=\frac{1}{n} \sum_{i=1}^{n} S A R_{i}
$$

Where, $S A R_{h}$ are the standardized abnormal returns of the hotel and tourism industry. Lastly, the standardized cumulative abnormal returns (SCAR) of each hotel and tourism industry company and the industry as whole is calculated by aggregating the SARs over the event window period $t=\left[-t_{1}, t_{2}\right]$ and $t$-statistics of SCAR is calculated by adjusting it for the number of days $(\mathrm{m})$ within the event window period given as:

$$
\begin{gathered}
\operatorname{SCAR}_{i}=\sum_{t=-t_{1}}^{t_{2}} S A R_{t} \\
t-\text { statistics }=\frac{1}{\sqrt{m}} S C A R_{i}
\end{gathered}
$$

The expected value of SCAR is zero in the absence of abnormal returns. The significance value of $t$-statistics indicates the impact of Covid-19 outbreak on stock returns of hotel and tourism Industry.

\section{Results and Discussion}

From Table 2, it can be observed that the mean returns of hotel and tourism industry companies have significantly decreased due to the Covid-19 outbreak. Before declaration of Covid-19 as pandemic, the mean negative returns were less than $1 \%$ which significantly increased to more than $1 \%$ negative mean returns after the outbreak of Covid19. Also, the variability of returns has also been increased after the announcement of pandemic. The maximum and minimum returns observed by all the companies have significantly widened after the event. The concentration of mean returns from positive to negative side can be observed by looking at the skewness coefficients.

Table 2. Descriptive Statistics

\begin{tabular}{llllr}
\hline \multicolumn{4}{l}{ Hotel and Tourism Individual Company's stock returns during Window Estimation Period } \\
\hline Company Name & Mean & Maximum & Minimum & Skewness \\
\hline Chalet Hotels Ltd. & -0.0059 & 9.3871 & -6.3906 & 0.5712 \\
E I H Ltd. & -0.1602 & 10.3179 & -6.9318 & 1.2180 \\
India Tourism Development Corporation Ltd. & 0.0352 & 18.2284 & -10.5307 & 1.2309 \\
Indian Hotels Co. Ltd. & -0.0387 & 10.0119 & -4.1200 & 1.5349 \\
Lemon Tree Hotels Ltd. & -0.2048 & 10.4059 & -7.8151 & 0.3495 \\
Mahindra Holidays \& Resorts India Ltd. & -0.0070 & 6.8546 & -7.7188 & 0.1819 \\
Market Returns & 0.0150 & 5.1581 & -2.1968 & 1.0968 \\
\hline Hotel and Tourism Individual Company's stock returns during Event Window Period & \\
\hline Company Name & Mean & Maximum & Minimum & Skewness \\
\hline Chalet Hotels Ltd. & -1.3790 & 8.1804 & -12.0335 & -0.2690 \\
E I H Ltd. & -1.1303 & 8.9186 & -19.4607 & -1.0481 \\
India Tourism Development Corporation Ltd. & -1.0698 & 14.4839 & -15.2934 & 0.1747 \\
Indian Hotels Co. Ltd. & -1.0586 & 12.6867 & -19.3644 & -0.7218 \\
Lemon Tree Hotels Ltd. & -1.7979 & 6.8920 & -17.8195 & -1.0975 \\
Mahindra Holidays \& Resorts India Ltd. & -0.9631 & 5.1083 & -15.9875 & -2.1386 \\
Market Returns & -0.0043 & 0.0741 & -0.1371 & -1.1264 \\
\hline
\end{tabular}

Note: The maximum event window period is $(-30,30)$ starting from 28 th Jan, 2020 to 28 th April, 2020. 
Table 3. The impact of Covid-19 on one-month stock returns (NR)

\begin{tabular}{lr}
\hline Company Name & $\begin{array}{r}\text { One-month Returns (in \%) } \\
\text { (March-April, 2020) }\end{array}$ \\
\hline Chalet Hotels Ltd. & -56.37 \\
E I H Ltd. & -49.32 \\
India Tourism Development Corporation Ltd. & -47.01 \\
Indian Hotels Co. Ltd. & -46.38 \\
Lemon Tree Hotels Ltd. & -66.92 \\
Mahindra Holidays \& Resorts India Ltd. & -44.37 \\
Nifty-500 & -22.94 \\
\hline
\end{tabular}

The results of Table 3 shows that the stock returns of all companies have significantly decreased after the covid-19 outbreak showing the severity of the pandemic on economy. The decline in the value of market index i.e. Nifty-500 is $22.94 \%$ whereas the decline in the stock returns of companies listed under it is approximately double, evidencing the presence of abnormal returns due to firm specific characteristics.

Table 4. Estimation of Stock Returns with OLS-Market Model

\begin{tabular}{lcccc}
\hline Company Name & C & B & Adjusted $R^{2}$ & $\begin{array}{c}\text { ARCH } \\
\text { Statistics }\end{array}$ \\
\hline Chalet Hotels Ltd. & $\begin{array}{c}-0.0084 \\
(0.9562)\end{array}$ & $\begin{array}{c}0.1634 \\
(0.3365)\end{array}$ & -0.0004 & $\begin{array}{c}0.0443 \\
(0.5334)\end{array}$ \\
\hline E I H Ltd. & $\begin{array}{c}-0.1719 \\
(0.2030)\end{array}$ & $\begin{array}{c}0.7751^{*} \\
(0.0000)\end{array}$ & 0.1141 & $\begin{array}{c}0.0057 \\
(0.9362)\end{array}$ \\
\hline India Tourism Development Corporation Ltd. & $\begin{array}{c}0.0115 \\
(0.9664)\end{array}$ & $\begin{array}{c}1.5766 * \\
(0.0000)\end{array}$ & 0.1146 & $\begin{array}{c}0.4190 * \\
(0.0000)\end{array}$ \\
\hline Indian Hotels Co. Ltd. & $\begin{array}{l}-0.0545 \\
(0.6404)\end{array}$ & $\begin{array}{c}1.0481^{*} \\
(0.0000)\end{array}$ & 0.2432 & $\begin{array}{c}0.0824 \\
(0.2462)\end{array}$ \\
\hline Lemon Tree Hotels Ltd. & $\begin{array}{c}-0.2165 \\
(0.1244)\end{array}$ & $\begin{array}{c}0.7777^{*} \\
(0.0000)\end{array}$ & 0.1062 & $\begin{array}{c}0.0211 \\
(0.7650)\end{array}$ \\
\hline Mahindra Holidays \& Resorts India Ltd. & $\begin{array}{c}-0.0194 \\
(0.8751)\end{array}$ & $\begin{array}{c}0.8256^{*} \\
(0.0000)\end{array}$ & 0.1495 & $\begin{array}{c}0.0525 \\
(0.4605)\end{array}$ \\
\hline
\end{tabular}

Note: Values in parenthesis indicates p-value of the test-statistics.

*indicates significant at $1 \%$.

In Table 4, the coefficient $\beta$ measuring the effect of market returns on stock returns of Hotel and Tourism companies listed in S\&P CNX Nifty-500 index is positive and statistically significant in case of 5 out of 6 companies indicating that a significant portion of company's stock returns are explained by market returns reflecting the market controlled behaviour of stock returns. The problem of heteroscedasticity (ARCH value is statistically significant at $1 \%$ ) is found significant in case of India Tourism Development Corporation Ltd leading to the adoption of conditional distribution with fatter tails (ARCH-GARCH type models) rather than normal distributions. GARCH $(1,1)$ model is used to calculate the estimated returns of India Tourism Development Corporation Ltd as GARCH $(1,1)$ model is more parsimonious and avoids overfitting. The results of returns estimation via GARCH $(1,1)$ model for India Tourism Development Corporation Ltd are presented in Table 6.

Table 5. Estimation of Stock Returns with GARCH $(1,1)-$ Market Model

\begin{tabular}{lcccccc}
\hline Company Name & $\mathrm{C}$ & $\beta$ & $\alpha_{0}$ & $\alpha_{1}$ & $\alpha_{2}$ & Adjusted $R^{2}$ \\
\hline India Tourism Development Corporation Ltd. & $\begin{array}{c}-0.0338 \\
(0.9039)\end{array}$ & $\begin{array}{c}1.3720^{*} \\
(0.0000)\end{array}$ & $\begin{array}{c}2.5359^{*} \\
(0.0003)\end{array}$ & $\begin{array}{c}0.3006^{*} \\
(0.0000)\end{array}$ & $\begin{array}{c}0.5400^{*} \\
(0.0000)\end{array}$ & 0.1124 \\
\hline
\end{tabular}

Note: Values in parenthesis indicates p-value of the test-statistics.

*indicates significant at $1 \%$.

The results of Table 5 suggest that, $\beta$ measuring the effect of market returns on conditional stock returns of India Tourism Development Corporation Ltd. traded in S\&P CNX Nifty-500 index is positive and statistically significant indicating that a significant portion of company's stock returns are explained by market returns.

In a conditional variance equation, $\alpha_{0}$ intercept term is the average volatility (called time independent component of volatility) is statistically significant indicating the persistence of average long-term volatility in the stock returns. $\alpha_{1}$, ARCH parameter is defined as the news about volatility from the past error term is also statistically 
Table 6. Standardized Cumulative abnormal returns (CAR)

\begin{tabular}{|c|c|c|c|c|c|c|c|}
\hline \multicolumn{8}{|c|}{ Over the event window period $(-10,0)$} \\
\hline Company Name & $\begin{array}{l}\text { Chalet Hotels } \\
\text { Ltd. }\end{array}$ & E I H Ltd. & $\begin{array}{c}\text { India Tourism } \\
\text { Development } \\
\text { Corporation Ltd. }\end{array}$ & $\begin{array}{l}\text { Indian Hotels } \\
\text { Co. Ltd. }\end{array}$ & $\begin{array}{l}\text { Lemon Tree } \\
\text { Hotels Ltd. }\end{array}$ & $\begin{array}{l}\text { Mahindra Holidays \& } \\
\text { Resorts India Ltd. }\end{array}$ & $\begin{array}{c}\text { Hotel and Tourism } \\
\text { Industry }\end{array}$ \\
\hline $\begin{array}{l}\text { Market Model } \\
\text { (MM) }\end{array}$ & $\begin{array}{l}-8.57^{*} \\
(-2.58)\end{array}$ & $\begin{array}{l}-7.22 * * \\
(-2.18)\end{array}$ & $\begin{array}{l}-11.52^{*} \\
(-3.47)\end{array}$ & $\begin{array}{l}-9.66 * \\
(-2.91)\end{array}$ & $\begin{array}{l}-13.80 * \\
(-4.16)\end{array}$ & $\begin{array}{c}-4.24 \\
(-1.28)\end{array}$ & $\begin{array}{l}-9.17^{*} \\
(-2.76)\end{array}$ \\
\hline $\begin{array}{l}\text { GARCH }(1,1) \\
\text { Model }\end{array}$ & & & $\begin{array}{l}-11.40^{*} \\
(-3.44)\end{array}$ & & & & \\
\hline \multicolumn{8}{|c|}{ Over the event window period $(0,10)$} \\
\hline Company Name & Chalet Hotels Ltd. & E I H Ltd. & $\begin{array}{c}\text { India Tourism } \\
\text { Development } \\
\text { Corporation Ltd. }\end{array}$ & $\begin{array}{l}\text { Indian Hotels } \\
\text { Co. Ltd. }\end{array}$ & $\begin{array}{l}\text { Lemon Tree } \\
\text { Hotels Ltd. }\end{array}$ & $\begin{array}{l}\text { Mahindra Holidays \& } \\
\text { Resorts India Ltd. }\end{array}$ & $\begin{array}{c}\text { Hotel and Tourism } \\
\text { Industry }\end{array}$ \\
\hline $\begin{array}{l}\text { Market Model } \\
\qquad(\mathrm{MM})\end{array}$ & $\begin{array}{l}-15.32^{*} \\
(-4.62)\end{array}$ & $\begin{array}{l}-29.02 * \\
(-8.75)\end{array}$ & $\begin{array}{l}-9.88 * \\
(-2.98)\end{array}$ & $\begin{array}{l}-21.90^{*} \\
(-6.60)\end{array}$ & $\begin{array}{l}-33.67^{*} \\
(-10.15)\end{array}$ & $\begin{array}{l}-22.18^{*} \\
(-6.69)\end{array}$ & $\begin{array}{l}-21.99^{*} \\
(-6.63)\end{array}$ \\
\hline $\begin{array}{l}\text { GARCH }(1,1) \\
\text { Model }\end{array}$ & & & $\begin{array}{l}-9.77^{*} \\
(-2.95)\end{array}$ & & & & \\
\hline
\end{tabular}

Note: Values in parenthesis indicates t-values of the test-statistics.

*indicates significant at $1 \%$

$* *$ indicates significant at $5 \%$

Table 7. Standardized Cumulative abnormal returns (CAR)

\begin{tabular}{|c|c|c|c|c|c|c|c|}
\hline \multicolumn{8}{|c|}{ Over the event window period $(-20,0)$} \\
\hline Company Name & $\begin{array}{l}\text { Chalet Hotels } \\
\text { Ltd. }\end{array}$ & E I H Ltd. & $\begin{array}{c}\text { India Tourism } \\
\text { Development } \\
\text { Corporation Ltd. }\end{array}$ & $\begin{array}{l}\text { Indian Hotels } \\
\text { Co. Ltd. }\end{array}$ & $\begin{array}{l}\text { Lemon Tree } \\
\text { Hotels Ltd. }\end{array}$ & $\begin{array}{l}\text { Mahindra Holidays \& } \\
\text { Resorts India Ltd. }\end{array}$ & $\begin{array}{c}\text { Hotel and Tourism } \\
\text { Industry }\end{array}$ \\
\hline $\begin{array}{l}\text { Market Model } \\
\text { (MM) }\end{array}$ & $\begin{array}{l}-9.05^{* *} \\
(-1.97)\end{array}$ & $\begin{array}{c}-7.34 \\
(-1.60)\end{array}$ & $\begin{array}{l}-11.53^{* *} \\
(-2.52)\end{array}$ & $\begin{array}{c}-10.18 * * \\
(-2.22)\end{array}$ & $\begin{array}{l}-5.46 \\
(-1.19)\end{array}$ & $\begin{array}{l}-6.86 \\
(-1.50)\end{array}$ & $\begin{array}{c}-8.40 * * * \\
(-1.83)\end{array}$ \\
\hline $\begin{array}{l}\text { GARCH }(1,1) \\
\text { Model }\end{array}$ & & & $\begin{array}{l}-11.31 * * \\
(-2.47)\end{array}$ & & & & \\
\hline \multicolumn{8}{|c|}{ Over the event window period $(0,20)$} \\
\hline Company Name & $\begin{array}{l}\text { Chalet Hotels } \\
\text { Ltd. }\end{array}$ & E I H Ltd. & $\begin{array}{c}\text { India Tourism } \\
\text { Development } \\
\text { Corporation Ltd. }\end{array}$ & $\begin{array}{l}\text { Indian Hotels } \\
\text { Co. Ltd. }\end{array}$ & $\begin{array}{l}\text { Lemon Tree } \\
\text { Hotels Ltd. }\end{array}$ & $\begin{array}{l}\text { Mahindra Holidays \& } \\
\text { Resorts India Ltd. }\end{array}$ & $\begin{array}{c}\text { Hotel and Tourism } \\
\text { Industry }\end{array}$ \\
\hline $\begin{array}{l}\text { Market Model } \\
\qquad(M M)\end{array}$ & $\begin{array}{l}-19.96^{*} \\
(-4.36)\end{array}$ & $\begin{array}{l}-22.48 * \\
(-4.91)\end{array}$ & $\begin{array}{l}-4.97 \\
-1.08\end{array}$ & $\begin{array}{l}-23.87^{*} \\
(-5.21)\end{array}$ & $\begin{array}{l}-42.40^{*} \\
(-9.25)\end{array}$ & $\begin{array}{l}-21.37^{*} \\
(-4.66)\end{array}$ & $\begin{array}{l}-22.51^{*} \\
(-4.91)\end{array}$ \\
\hline $\begin{array}{l}\text { GARCH }(1,1) \\
\text { Model }\end{array}$ & & & $\begin{array}{c}-4.75 \\
(-1.04)\end{array}$ & & & & \\
\hline
\end{tabular}

Note: Values in parenthesis indicates t-values of the test-statistics.

*indicates significant at $1 \%$.

$* *$ indicates significant at $5 \%$.

$* * *$ indicates significant at $10 \%$.

significant implying that volatility of stock returns is sensitive to the previous period residual variance. $\alpha_{2}$ the GARCH parameter i.e., previous period conditional variance is also found statistically significant indicating that volatility of stock returns in the current period is strongly related to its volatility in the previous period. Both the ARCH $\left(\alpha_{1}\right)$ and GARCH parameter $\left(\alpha_{2}\right)$ are satisfying the non-negativity condition. In the GARCH model parameters of conditional variance equation $\alpha_{0}, \alpha_{1}$ and $\alpha_{2}$ should be positive for non-negativity condition which is holding true and providing evidence in support of returns estimation via GARCH $(1,1)$ model for India Tourism Development Corporation Ltd.

Table 6 presents the Cumulative Abnormal Returns of hotel and tourism companies listed in the Nifty-500 by OLS market model and GARCH $(1,1)$ model. It can be seen from the table that CARs during the window event $[-10,0]$ i.e. 10 days prior to the declaration of covid-19 as pandemic were negative and statistically significant at $1 \%$ level in case of most companies indicating the presence of Covid-19 impact on Hotel and Tourism industry. Abnormal returns were witnessed before the announcement because this global event was started been observed by the world before its official announcement by WHO and the markets were reacting accordingly. In comparison to the CARs that were observed before declaration of covid-19 outbreak, the CARs over the event window [0,10] were 
negative and statistically significant at $1 \%$ for the individual hotel and tourism company as well as for the overall hotel and tourism industry. It can be observed from the results of Table 6, that the magnitude of impact is higher on returns (more than double) after the official announcement of covid-19 as pandemic by WHO. The abnormal returns of hotel and tourism industry were negative $9.17 \%$ 10-days prior to the event which significantly increased to negative $21.99 \%$ after the event showing significant decline in the hotel and tourism industry in India.

Similarly, CARs (Table 7) were estimated for the event windows $[-20,0]$ and $[0,20]$. Almost similar results were observed as were obtained during the event windows $[-10,0]$ and $[0,10]$. The magnitude of impact is found to be higher after the declaration of pandemic and CARs were statistically negative. The cumulative abnormal returns of the hotel and tourism industry were negative $22.51 \%$ within 20 active trading days of the market.

Table 8. Standardized Cumulative abnormal returns (CAR)

\begin{tabular}{|c|c|c|c|c|c|c|c|}
\hline \multicolumn{8}{|c|}{ Over the event window period $(-30,0)$} \\
\hline Company Name & $\begin{array}{l}\text { Chalet Hotels } \\
\text { Ltd. }\end{array}$ & E I H Ltd. & $\begin{array}{l}\text { India Tourism } \\
\text { Development } \\
\text { Corporation Ltd. }\end{array}$ & $\begin{array}{l}\text { Indian Hotels } \\
\text { Co. Ltd. }\end{array}$ & $\begin{array}{l}\text { Lemon Tree } \\
\text { Hotels Ltd. }\end{array}$ & $\begin{array}{l}\text { Mahindra Holidays \& } \\
\text { Resorts India Ltd. }\end{array}$ & $\begin{array}{l}\text { Hotel and Tourism } \\
\text { Industry }\end{array}$ \\
\hline $\begin{array}{l}\text { Market Model } \\
(M M)\end{array}$ & $\begin{array}{l}-8.75 \\
(-1.57)\end{array}$ & $\begin{array}{l}-8.44 \\
(-1.52)\end{array}$ & $\begin{array}{l}-12.51^{* *} \\
(-2.25)\end{array}$ & $\begin{array}{l}-11.04^{* *} \\
(-1.98)\end{array}$ & $\begin{array}{l}-3.54 \\
(-0.64)\end{array}$ & $\begin{array}{l}-8.47 \\
(-1.52)\end{array}$ & $\begin{array}{l}-8.79 \\
(-1.58)\end{array}$ \\
\hline $\begin{array}{l}\text { GARCH }(1,1) \\
\text { Model }\end{array}$ & & & $\begin{array}{l}-12.18 * * \\
(-2.19)\end{array}$ & & & & \\
\hline \multicolumn{8}{|c|}{ Over the event window period $(0,30)$} \\
\hline Company Name & $\begin{array}{l}\text { Chalet Hotels } \\
\text { Ltd. }\end{array}$ & E I H Ltd. & $\begin{array}{l}\text { India Tourism } \\
\text { Development } \\
\text { Corporation Ltd. }\end{array}$ & $\begin{array}{l}\text { Indian Hotels } \\
\text { Co. Ltd. }\end{array}$ & $\begin{array}{l}\text { Lemon Tree } \\
\text { Hotels Ltd. }\end{array}$ & $\begin{array}{l}\text { Mahindra Holidays \& } \\
\text { Resorts India Ltd. }\end{array}$ & $\begin{array}{l}\text { Hotel and Tourism } \\
\text { Industry }\end{array}$ \\
\hline $\begin{array}{l}\text { Market Model } \\
(M M)\end{array}$ & $\begin{array}{l}-28.44^{*} \\
(-5.11)\end{array}$ & $\begin{array}{l}-20.34^{*} \\
(-3.65)\end{array}$ & $\begin{array}{l}-3.50 \\
-0.63\end{array}$ & $\begin{array}{l}-21.71^{*} \\
(-3.90)\end{array}$ & $\begin{array}{l}-41.79^{*} \\
(-7.50)\end{array}$ & $\begin{array}{l}-23.82^{*} \\
(-4.28)\end{array}$ & $\begin{array}{l}-23.27^{*} \\
(-4.18)\end{array}$ \\
\hline $\begin{array}{l}\text { GARCH }(1,1) \\
\text { Model }\end{array}$ & & & $\begin{array}{l}-3.17 \\
(-0.57)\end{array}$ & & & & \\
\hline
\end{tabular}

Note: Values in parenthesis indicates t-values of the test-statistics.

*indicates significant at $1 \%$.

$* *$ indicates significant at $5 \%$.

Moreover, we estimated CARs (Table 8) during the 30-days prior to the covid-19 outbreak to incorporate the wider aspect of the event but CARs were found not be statistically significant 30 days prior to the announcement of covid-19 indicating that Covid-19 outbark did not had a significant negative impact on hotel and tourism industry performance during this period i.e. 30 days prior to the event but this effect is found to be significant 30 days after the outbreak of covid-19 as presented in table 8. The cumulative abnormal returns of Lemon Tree Hotels Ltd. are negative $41.79 \%$. It is the highest decline observed in the abnormal returns over the event window period evidencing the inclusion of wider event window period.

Our results were similar to the findings by (Chen et al., 2007; McTier et al., 2013; Alfaro et al., 2020; Al-Awadhi et al., 2020; Liu et al., 2020; Apergis and Apergis, 2020; Bash, 2020). For India, the negative cumulative abnormal mean returns for hotels and tourism stocks were much higher than that observed by (Alfaro et al., 2020). Our results were contrary to the finding by (Loh, 2006) who could not establish the negative impact of SARS on stock returns.

\section{Conclusion and Managerial Implications}

This event study approach provides hotel managers with insights on how stock returns get affected by pandemics like Covid 19. Government Policy initiatives, Media coverage of spread of virus and deaths, Lack of Healthcare infrastructure and medicines induce fear in the minds of investors. Fearful investors amplify the impact of every such negative news on the stock return of hospitality industry. Lockdown is a new reality across the globe weakening the future sentiments of revival of hospitality industry in future. While some Hotel groups have responded positively by offering their premises as quarantine centres were doctors and patients can be served. This type of agile management followed by some hospitals is the need of the hour as it may facilitate them to partly pay their variable costs and induce a positive sentiment.

We have analysed the impact of Covid-19 pandemic on stock returns of seven hotels listed on National Stock Exchange (NSE). We analysed the results for an event window of ten days, twenty days and thirty days from 11th March 2020. World Health Organisation announced Covid-19 as a pandemic on 11th March 2020. A significant decrease was observed in the mean returns of hotel and tourism industry companies due to Covid-19 outbreak. It was found that a decrease of more than 1 per cent negative mean returns was observed post Covid-19. Variance 
in returns also increased in post Covid-19 period. Skewness showed that the concentration of mean returns also shifted from positive to negative. The severity of negative impact was also very high for tourism and hospitality industry. The decline in the stock returns of tourism and hotel industry was almost double of the index Nifty 500. This clearly pointed out the abnormal negative returns during the period. Abnormal negative returns were observed even before the announcement date as Covid-19 was affecting the world from December 2019. However, the abnormal negative returns before the announcement date were much less than the abnormal negative returns post the announcement. The announcement magnified the negative abnormal returns of hotel and tourism industry stocks. The cumulative abnormal returns of hotel and tourism industry were negative 22.51 per cent for an event window of 20 days post the WHO announcement. However, extending the event window to 30 days from the date of announcement, we found that Cumulative abnormal returns were statistically insignificant prior to the announcement. However, results were found significant post the announcement with one of the stocks experiencing a cumulative negative returns -41.79 per cent.

Based on our findings, various investment strategies can be formulated to either increase gains or minimise losses. Investors in hotel stocks can learn from this finding and exit prior to the second wave of Covid-19. Day traders can make gains by short selling on daily basis during the downfall period. Mutual funds, Domestic Institutions Investors and Foreign Institutional Investors can take benefit from this opportunity and invest heavily in these stocks when they bottom. They may make gains over a long run period. The findings are also relevant for Hotel industry which may like to convert to Covid-19 care centres. This will enable them to sustain financially during the second wave while serving for a social cause. Also, many hotels may like to tie-up with corporate and create "WFH=Work from Hotel" were by an entire cottage or a set of rooms or villas may be taken up by a particular corporate for their employee who have become tired of Work from Home.

An attempt is being made in this study to not only make an academic contribution but also help prepare investors in case a second or third wave of Covid-19 re-appears. The paper also points out to the role of media to try to intelligently present facts in future without adding to fear and anxiety amongst its readers and listeners. There exists a lot of empirical works linking pandemics with stock returns. However, this is one of the very few first papers that the analysed the impact of Covid-19 on publically listed Hotel and Tourism Stocks in India. From the review, it can be observed that event methodology has been extensively used internationally but limited papers are present analysing Indian stock market data. The findings are very relevant to a large group of investors, hotels and analysts in general.

\section{Limitations and Further Research}

The world has never seen a pandemic like Covid-19 in last hundred years. Hence, the uncertainty associated with the growth in the number of infected persons and deaths is making it extremely difficult to analyse and predict future. One of the limitations of this paper is that it is uncertain how long this pandemic is here to stay. We could undertake tests similar to the ones conducted by Nippani and Washer (2004) and Loh (2006), if we could have divided the data as Pre-Event Sub Period, Covid-19 Sub-Period and Post-Event Sub Period. This shall be possible only once the pandemic is officially over.

In future, this work can be expanded to include related sectors like airline and logistic sectors. In future, the researchers can also try to find the impact on trading activity over longer periods. One may also use the prediction model developed by (Alfaro et al., 2020) for relating the infection rate and stock returns.

\section{References}

Al-Awadhi, A.M., Alsaifi, K., Al-Awadhi, A., Alhammadi, S., 2020. Death and contagious infectious diseases: Impact of the covid-19 virus on stock market returns. Journal of Behavioral and Experimental Finance 27. URL: https: //doi.org/10.1016/j.jbef.2020.100326.

Alfaro, L., Chari, A., Greenland, A., Schott, P., 2020. Aggregate and firm-level stock returns during pandemics, in real time. National Bureau of Economic Research Working Paper Series 26950.

Apergis, N., Apergis, E., 2020. The role of covid-19 for chinese stock returns: evidence from a garchx model. Asia-Pacific Journal of Accounting and Economics URL: https://doi.org/10.1080/16081625.2020.1816185.

Baker, S.R., Bloom, N., Davis, S.J., Kost, K., Sammon, M.C., Viratyosin, T., 2020. The unprecedented stock market impact of covid-19. Review of Corporate Finance Studies 9.

Bash, A., 2020. International evidence of covid-19 and stock market returns: An event study analysis. International Journal of Economics and Financial Issues 10(4). URL: https://doi.org/10.32479/ijefi.9941.

BBC News, 2020. India coronavirus: \$22bn bailout announced for the poor. URL: https://www.bbc.com/news/ world-asia-india-52047263. 2020-03-27.

Bollerslev, T., Chou, R.Y., Kroner, K.F., 1992. Arch modeling in finance: A review of the theory and empirical evidence. Journal of Econometrics 52(1-2). URL: https://doi.org/10.1016/0304-4076(92) 90064-X.

Brooks, C., 2019. Introductory Econometrics for Finance. Cambridge University Press, Cambridge. URL: https: //doi.org/10.1017/9781108524872. 
Chen, M.H., Jang, S.C., Kim, W.G., 2007. The impact of the sars outbreak on taiwanese hotel stock performance: An event-study approach. International Journal of Hospitality Management 26(1), 200-212. URL: https://doi. org/10.1016/j.ijhm.2005.11.004.

Johns Hopkins University, 2020. Johns Hopkins coronavirus resource center. URL: https://www. jhu.edu/.

Lee, C.C., Lee, C.C., Wu, Y., 2021. The impact of covid-19 pandemic on hospitality stock returns in china. International Journal of Finance and Economics URL: https://doi.org/10.1002/ijfe.2508.

Liu, H., Manzoor, A., Wang, C., Zhang, L., Manzoor, Z., 2020. The covid-19 outbreak and affected countries stock markets response. International Journal of Environmental Research and Public Health 17(8). URL: https: //doi.org/10.3390/ijerph17082800.

Loh, E., 2006. The impact of sars on the performance and risk profile of airline stocks. International Journal of Transport Economics 33(3), 401-422. URL: https://www.jstor.org/stable/42747811.

McTier, B.C., Tse, Y., Wald, J.K., 2013. Do stock markets catch the flu. Journal of Financial and Quantitative Analysis 48(3), 979-1000. URL: https://doi.org/10.1017/S0022109013000239.

Ministry of Health \& FW, Government of India, 2020. Government of india additional travel advisory for novel coronavirus disease (COVID-19). URL: https://www.mohfw.gov.in/pdf/Traveladvisory.pdf. 2020-03-19.

Mittal, S., Sharma, D., 2021. The impact of covid-19 on stock returns of the indian healthcare and pharmaceutical sector. Australasian Accounting, Business and Finance Journal 15(1 Special Issue). URL: https://doi.org/10. 14453/aabfj.v15i1.2.

Narayan, P.K., Phan, D.H.B., Liu, G., 2021. COVID-19 lockdowns, stimulus packages, travel bans, and stock returns. Finance Research Letters 38. URL: https://doi.org/10.1016/j.frl.2020.101732.

Nippani, S., Washer, K.M., 2004. SARS: A non-event for affected countries' stock markets? Applied Financial Economics 14(15). URL: https://doi.org/10.1080/0960310042000310579.

Shereen, M.A., Khan, S., Kazmi, A., Bashir, N., Siddique, R., 2020. COVID-19 infection: Origin, transmission, and characteristics of human coronaviruses. Journal of Advanced Research 24. URL: https://doi.org/10.1016/j.jare. 2020.03 .005$.

Shive, S., 2010. An epidemic model of investor behavior. Journal of Financial and Quantitative Analysis 45(1). URL: https://doi.org/10.1017/S0022109009990470.

The Economic Times, 2020. Global economy could shrink by almost $1 \%$ in 2020 due to covid19 pandemic: United Nations. URL: economictimes.indiatimes.com/news/international/business/ global-economy-could-shrink-by-almost-1-in-2020-due-to-covid-19-pandemic-united-nations/articleshow/ 74943235.cms?utm_source=contentofinterest\&utm_medium=text\&utm_campaign=cppst. 2020-04-02.

The Hindu BusinessLine, 2020. Hotels, tourism hit hard by covid-19 impact: JLL India. URL: https://www . thehindubusinessline.com/economy/hotels-tourism-hit-hard-by-covid-19-impact-jll-india/article31385683.ece. 2020-04-20.

Zhang, D., Hu, M., Ji, Q., 2020. Financial markets under the global pandemic of COVID-19. Finance Research Letters 36. URL: https://www.sciencedirect.com/science/article/pii/S1544612320304050. 